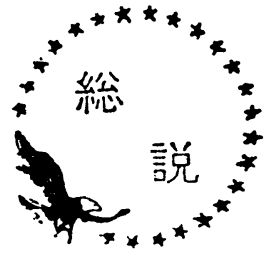

は じめに

LNG は $-162^{\circ} \mathrm{C}$ という低温液体であるため，この 関係装置に使用される材料や工作法には特別の吟味が 要求されるが，断熱の問題についても例外でない。

一般に, このような低温の断熱方法において最も注 意しなければならない点は，

(1) 断熱材が吸湿しないよう十分な防湿層を作成す ること

（2）線膨張係数に由来する断熱材そのもの，あるい は金属などと相関する変形, 熱㥕力を処理するこ と

の 2 点にあると考えられる。

本文ではタンク，船舶および配管の断熱法につき， 事例を中心に集めた。個々の対象物につき詳細に述べ ることは限られた紙数では困難であるが，上記 2 点を いかに克服しているか御理解いただければ幸いであ る。

\section{LNG 貯蔵タンクの断熱}

\section{1-1 地上 2 重殼タンク}

図 1 は金属 2 重款タンクの代表的な説明図である。 外側のタンクは防湿層としての役割も重要であって, 防熱材の吸湿による性能劣化を防いでいる。内外殼は 共に温度および圧力の変化を受け, 相対的な変位が発 生するのでブランケットが内殼外側に取り付けられ る。この材料は主に数インチ厚のグラスウールマット である。パーライト層の厚みは大体 3 〜 5 フィートで これはむしろ建設作業のための必要空間であると言わ

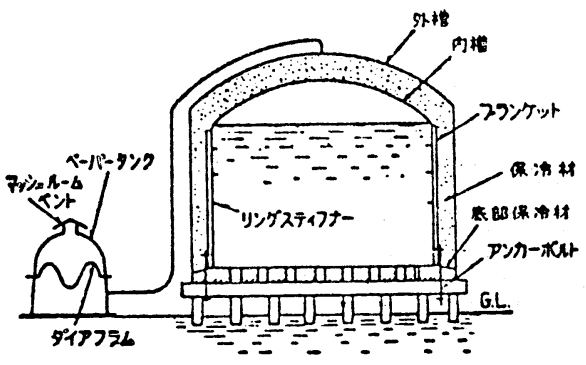

図 1 地上金属 2 重殼タンク

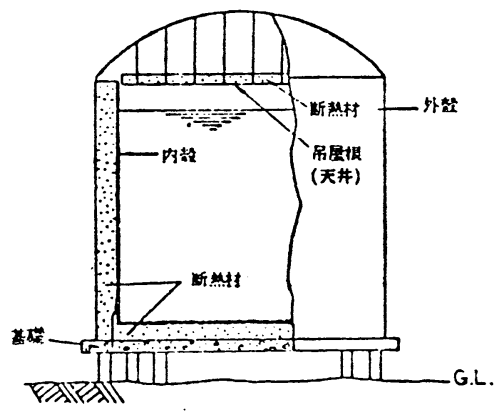

図 2 吊天井形式

れる。

図 2 に示すような吊天井方式の採用により，いろい ろの点で改良された。天井部の防熱材は軽量なグラス ウールや,さらに安価なミネラルウールなどが適して いる。

底部には強度の大きい防熱材が必要で, 主にパーラ イトボードやフォームグラス, 時には塩ビフォーム が，またパーライトコンクリートブロックやパーライ トコンクリートの現場打設もよく行なわれる。図 3 は 東京瓦斯根岸の地上タンクに用いられた方法であ $\eta^{1)}$ ，米国の LNG タンクでも幾つかの例がある。図 4 はバルセロナのタンクである。内殼が P S コンクリ 一トである点は特異であるが，防熱方式はパーライト

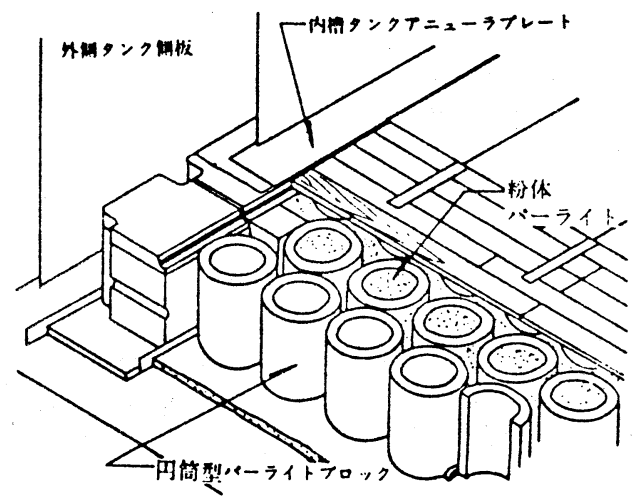

図 3 底面耐圧防熱構造の一例 


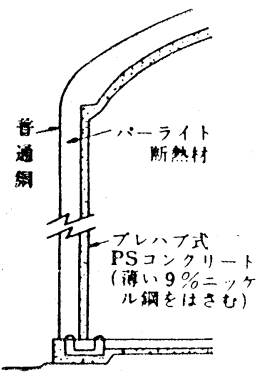

図 4 バルセロナの地上タンク
粉と PVCフォームで思想的には金属 2 重殼と同じで ある。ラスペチアの金属 2 重殼タンクの防熱は，底面 パーライトコンクリートブロックノルーズパーライト 紛/木構造, 側面グラスウール, 頂部パーライト粉と なっている。

1-2＼cjkstart地上または地下のメンブレンタンク

地上金属重殼タンクはほとんで確立した技術となっ ており，世界にもその実績が多いが，その他のタンク 形式もいろいろ研究されている。

表 1 に種々の形式のタンクの例を示す。ここに数は

表 1 金属 2 重殼, 凍結式を除く LNG などのタンク

\begin{tabular}{|c|c|c|c|c|}
\hline 量 $(\mathrm{k} l)$ & 型 & 所 & 所 & 建 \\
\hline 200 & コンクリート・半地下 & AGA & Illinoi & 6 \\
\hline 2,000 & コンクリート・地上 & Gaz de France & Nante & 67 \\
\hline 6,000 & コンクリート・半地下 & BS 液化ガス & 苫小牧 & \\
\hline $40,000 \times 2$ & コンクリート・地上 & Spain Esso & Barucelona & \\
\hline 95,000 & コンクリート・半地下 & Texas Eastern Gas & New York & \\
\hline $4,000 \times 2$ & 金属·地上 & 鐘 化 & 水 島 & \\
\hline 10,000 & コンクリート・地下 & 東京瓦斯 & 根 岸 & \\
\hline $60,000 \times 3$ & コンクリート・地下 & 東京瓦斯 & 袖ケ浦・根岸 & 建 \\
\hline 65,000 & コンクリート・半地下 & Philadelphia Electric & Penn. & \\
\hline $92,000 \times 2$ & コンクリート・半地下 & Philadelphia Gas & Penn. & \\
\hline $143,000 \times 2$ & コンクリート・半地下 & Distrigas Corp. & New York & \\
\hline
\end{tabular}

少ないがとりあげたのは, それぞれ独得の興味ある工 夫がなされているからである。表に従い順次図を掲げ る。図 5 の AGA のテストタンクはコンクリート壁 の外側に断熱材があり, ニニークな形となっている。 このタンクでは，コンクリートが低温に対して十分な

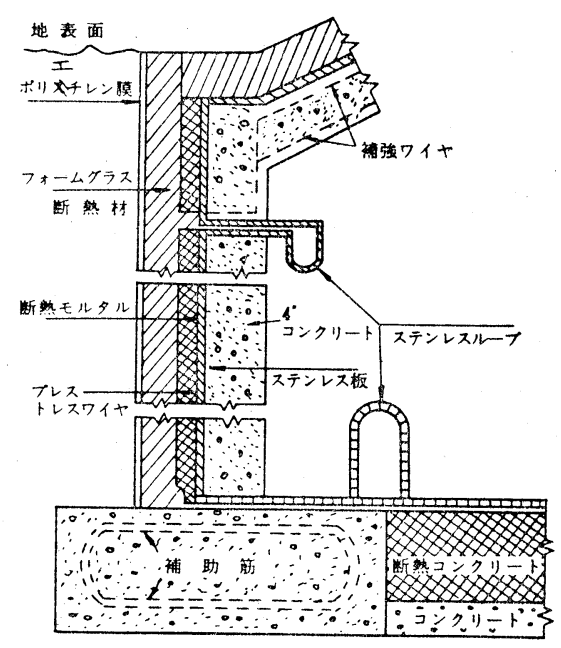

図 $5 \quad A G A$ 式コンクリートタンク

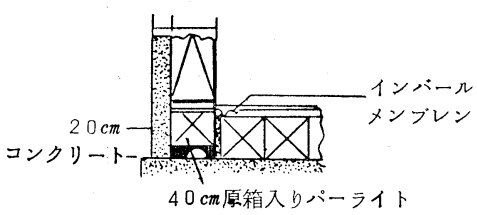

図 6 ナンテの地上タンク

強度があることを立証した点が重要である。図 6 のナ ンテのタンクは LNG 船ポーラアラスカの原型をなす ものである22。次の苫小牧の LPG タンクは BS 液化 ガス方式のメンブレンのテストタンクである ${ }^{31}$ 。バル セロナのタンクについてはさきに触れた。テキサス， イースタンのタンクの構造は非常にざん新で, 外側に PS コンクリート, 次いでその内側に 8 インチ厚のポ リウレタンフォーム, そしてライナーはダクロン (ポ リエステル繊維), アルミ蒸着マイラー (ポリエステ ルフィルム）の貼り合わせたものである。防熱材もフ イルムもタンクに固定せず, 内側に組まれたトラスか ら弾性的に押えられている。フィルムは損傷を防ぐた め防熱材の間に㣣まれ, 底面は保護のコンクリートブ ロックが敷かれている。天井はアルミデッキの上に 12 


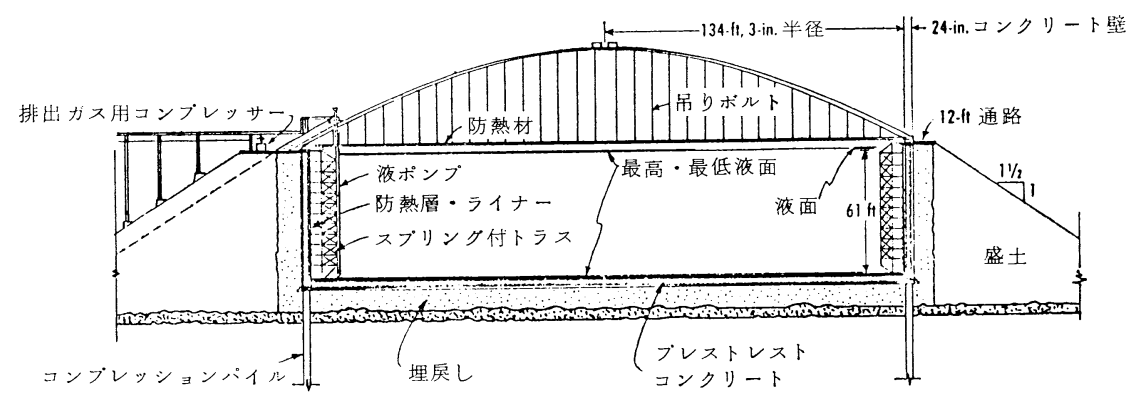

図 7 テキサス・イースタンガスの半地下タンク

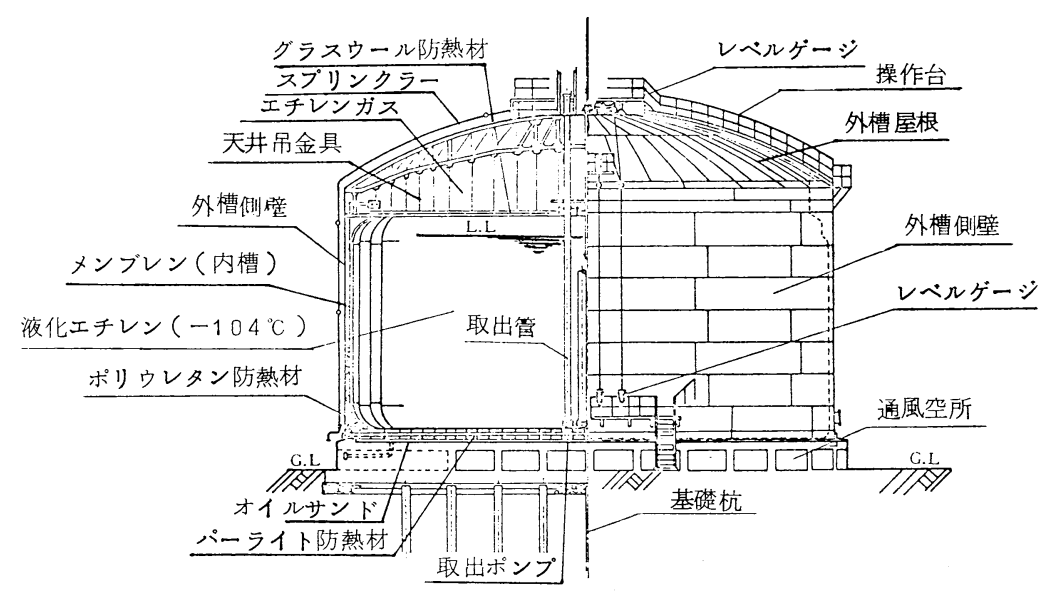

図 8 鐘化水島の LEG メンブレンタンク

インチ厚のポリウレタンフォームになっている4)。本 タンクは70年 3 月頃から稼動している5)(図7)。

さきに述べた BS ガスメンブレン式の地上タンクが 数基建設された。図 8 はこの一例を示すものである3”。

日本における地下タンク構造の一つの結論が東京瓦 斯根岸の 1 万 $\mathrm{m}^{3}$ タンクである。図 9 にその形状を示 す $^{6)}$ 。図10に示すようなセグメント工法が用いられて いる7)。現在同方式で 6 万 $\mathrm{m}^{3}$ のタンクが建設されて いる。図11にテクニガスが提唱する構造を示す。低温 側に合板があり，メンブレンが随所にこれに固定され ていることが特長である8)。

表 1 の末尾, 米国において大型コンクリートタンク が相ついで建設されている。これらはダイク方式がと られていることが特長である。代表的な形状を図12に 示す9)。

\section{LNG 船の断熱}

表 2 は現在就航中または建造中のタンカーの分類で ある。一般に船舶での特長は, 独立タンク式とメンブ
レンタンク式の 2 系統があることのほか, 安全のため の 2 次障壁が要求されていることである。以下表に従 って記す。

\section{2-1 独立タンク式 $\mathrm{LNG}$ 船}

図13のメタンパイオニアの防熱は, バルサと2 次障 壁を兼ねた合板からなっている(10)。図14のメタンプリ ンセスではパネルの厚みが減少してグラスウールが加 えられている。さらにパネルの相当な部分を, 図15の ごとくポリウレタンフォームに置きかえる提案がなさ れている(10)。次にエッソの 4 隻は同型船で, 図16の形 状である。2 次障壁を兼ねた 2 重のアルミタンクが特 長で，防熱材は合板を㣣んでポリウレタンフォームが ボルトで取り付けられている10)。表にはないがマック ミューレン方式もこれに似た構造である（眓17)。近 いうちに建造されると言われる(0)。

図18のジュールベルンはメタンプリンセスと並んで 本格的な LNG 船の先駆となったものである。構造は 地上金属 2 重殼に類似している。底面および側面の 2 

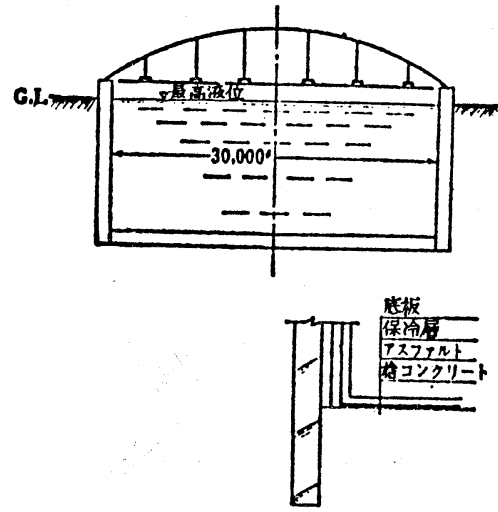

型式 セグメント式地下タンク

実容量 $10,000 \mathrm{kl}$

主要寸法 内径 30,000 mm、液高 14,150 m

主要材料 タンク塈：コンポジットシェ ルセグメント、鉄 筋コンクリート

タン底部：土丹層

タンク屋根：低炭素鐉

メンブレン：オーステナイト鋼

保冷材 硬質ウレタンフォーム

図 9 東京瓦斯根岸の地下タンク
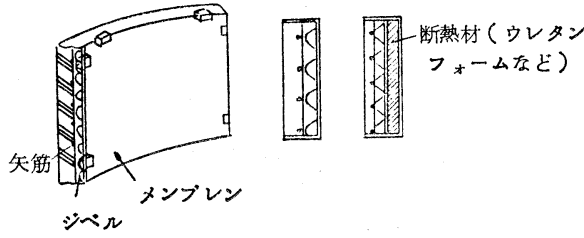

図10防熱材付セグメント

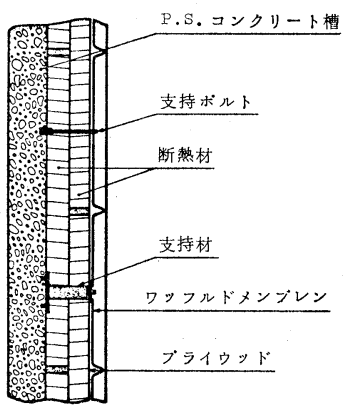

図11 テクニガス式タンク（側面）

次障壁の材質および位置が面白い。

球型の独立タンクを搭載する形式が最近注目されて いる。図19, 図20とそれぞれ別個に開発された。サイ ズの差もあろらが両者のタンクの支持方法および防熱 方法が異なっている。

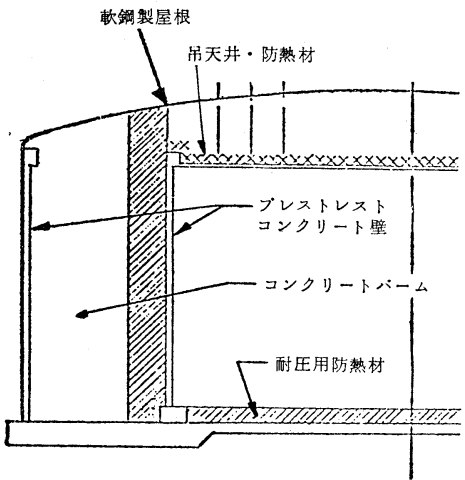

図12 ダイク式地上, 半地下タンク
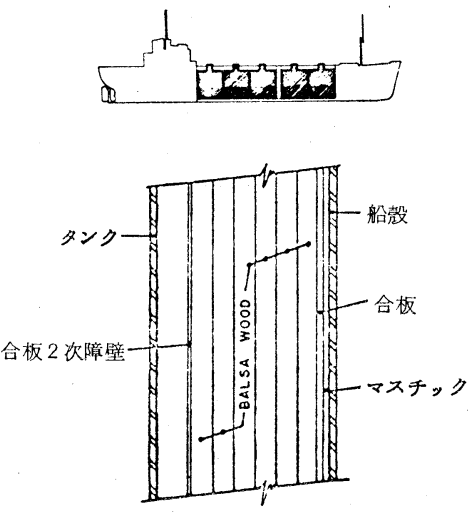

図13メタン・パイオニアと側面詳細
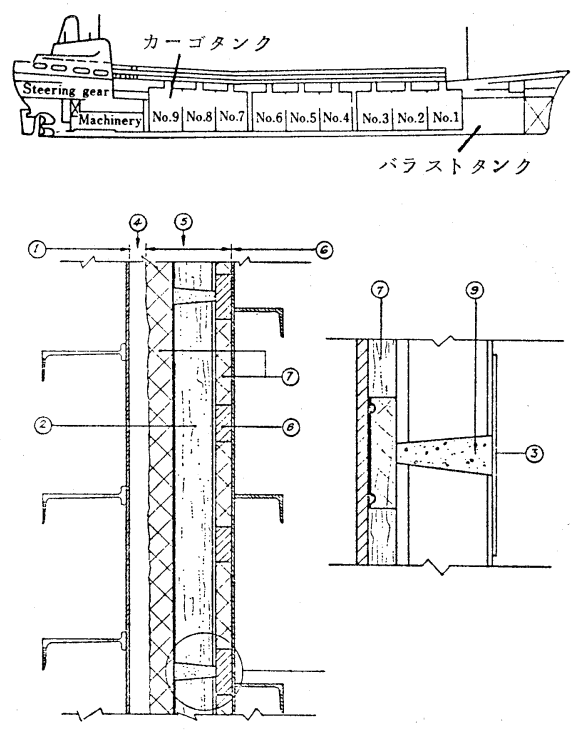

図14メタン・プリンセス 
表 2 主な LNG 船の 分類

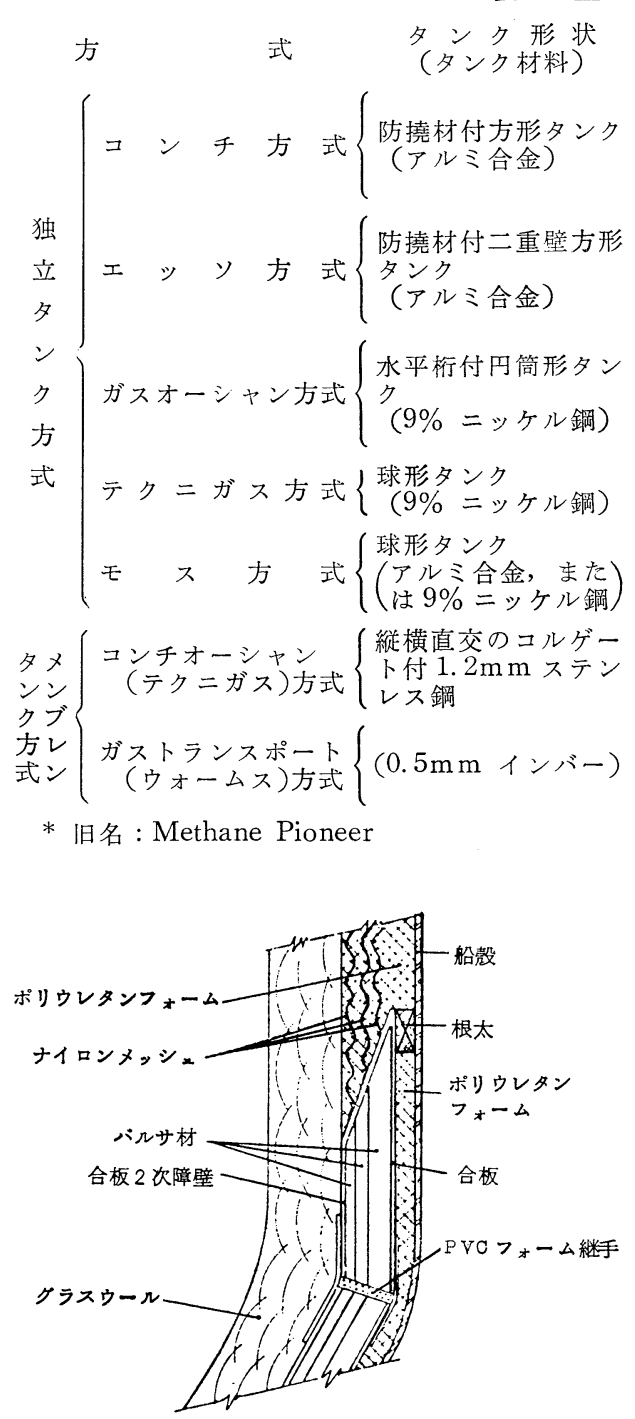

図15 コンチ方式の改良断熱構造
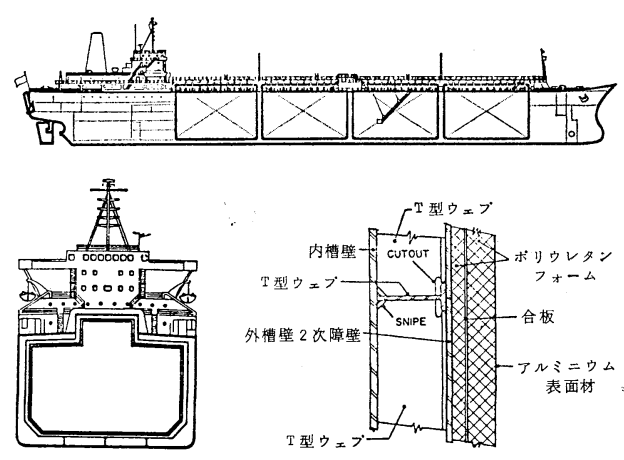

図16 エッソ方式 LNG 船
防 熱材船 名(タンク容積 $\mathrm{m}^{3}$ ) 註

底部, 側部 : バル Aristotle $(5,123)^{*}$ 図 3

$\left.\begin{array}{rl}\text { サ積層材 } & \text { Methane Princess } \\ \text { 上部: }\end{array}\right\}(27,000)$ 図14

$\left.\begin{array}{lll}\text { 上部:グラスファ } & \text { Methane Progress }\end{array}\right\}(27,000)$ 図15

$\left.\begin{array}{ll}\text { ポリウレタンフォ } & \begin{array}{l}\text { Esso Brega } \\ \text { Esso Rortovenere } \\ \text { Esso Liguria } \\ \text { Laieta }\end{array}\end{array}\right\}(40,000)$ 図16

底部：クレゲセル

側部, 上部：クレ Jules Verne $(25,500)$ 図18

パーライト Euclides (4,000)

図19

ポリウレタンフォ 29,000 型及び 87.600 型を建造中 四20
ームなど

バルサ積層材罗21

Descartes $(50,000)$ 図22

$\left.\begin{array}{ll}\text { パーライト } & \text { Polar Alaska } \\ \text { (木箱に充塤) } & \text { Arctic Tokyo }\end{array}\right\}(71,500) \quad$ 図23

Hassi R'mel (40,000)

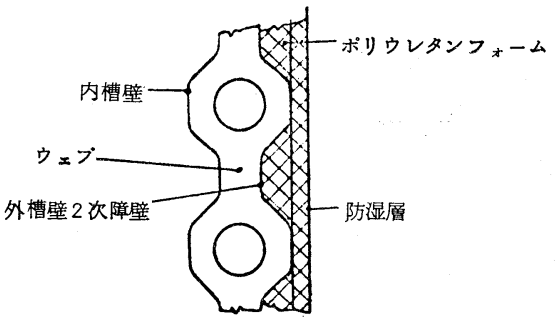

図17 マック・ミューレン方式の独立タンク
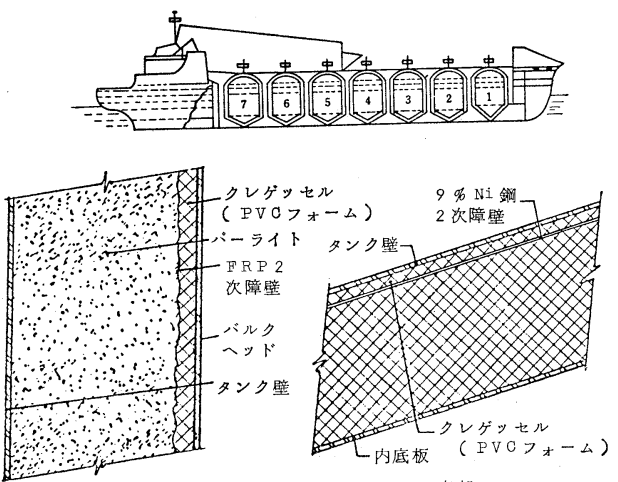

(a) 頂部 - 㑡部

(b) 底部

図18 ジュール・ベルン

2-2 メンブレンタンク式 LNG 船

以上の独立タンク方式に比べ, 積載効率の大きいと 


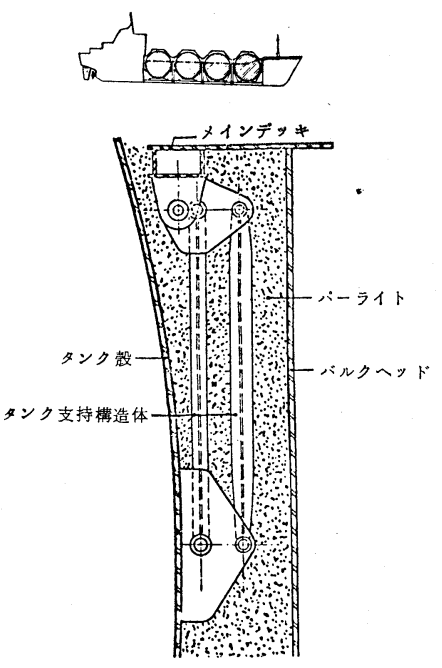

図19 ユークリッド
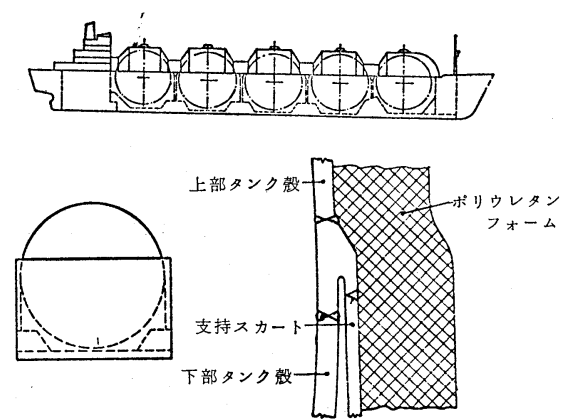

図20 モス型独立タンク船

いわれるメンブレン船も種々の困難を克服して実現し つつある。

テクニガスのメンブレン方式の実験船であるピタゴ リーは, 図21に示すような 2 重構造である。このしわ 付メンブレンと前記コンチのバルサパネルの特長を組

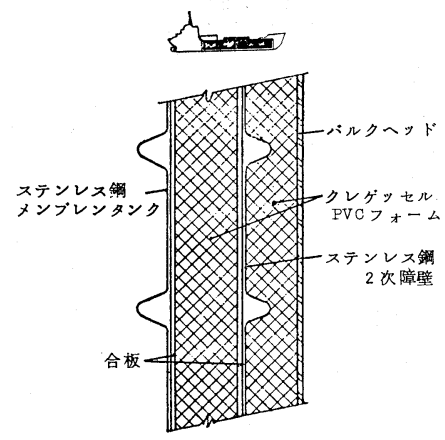

図21 ピタゴリー
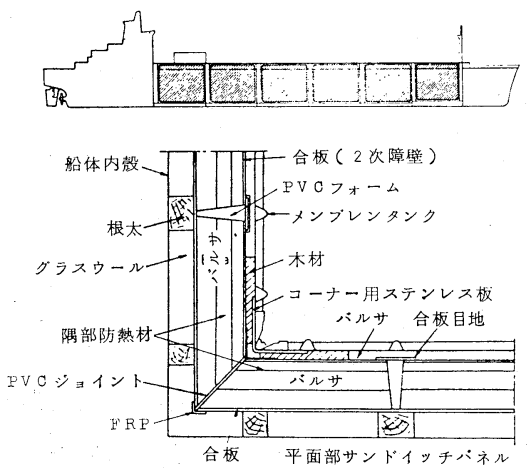

図22 デスカルテ
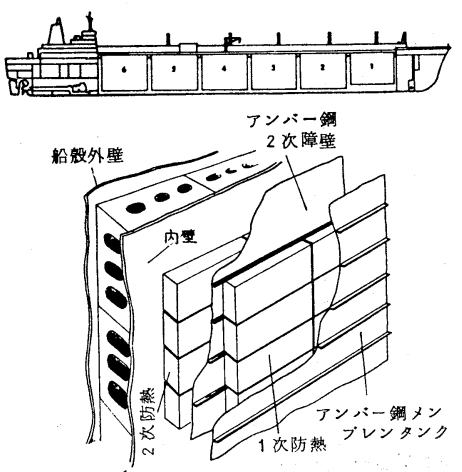

図23 ポーラー・アラスカ

み合わせたものがコンチオーシャン方式と呼ばれるも ので，第 1 船，デスカートの構造を図 22 に示す。ポー ラアラスカはすでに多く紹介されているがウォームス 方式の代表である。眓23に示すように箱入りパーライ トとインバールメンブレンの 2 重構造が特長である。

BS 液化ガス方式は頂部のみ固定された，しわのな い特異な形式でセミメンブレンとも言われる。さきに 陸上での例を述べたが，図24は LPG 船での構造例で ある。LEG 船もこの方式で建造された ${ }^{3)}$ 。なお LEG 船は外国にも例が多いが, 国内でもこのほか独立タン

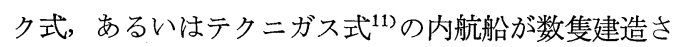

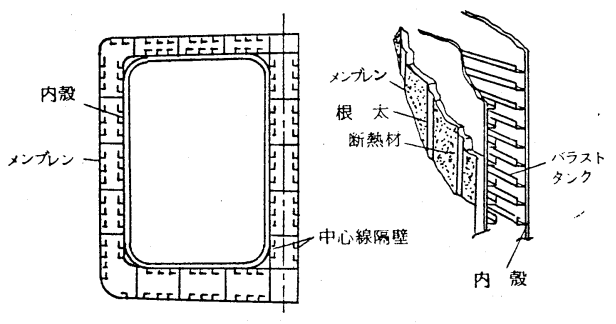

図24 BS 式メンブレン船 (LPG) 


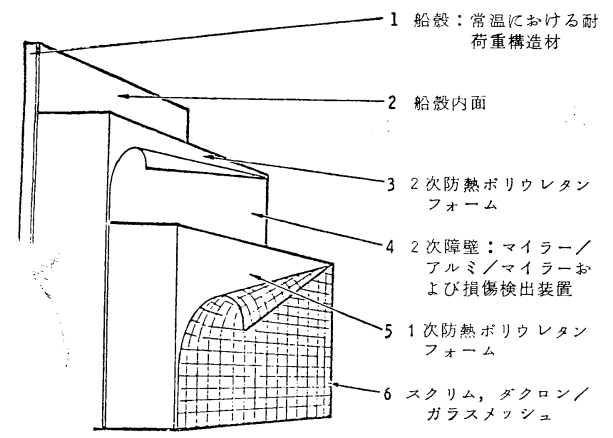

図25 ウェット・ウォール法

れた。いずれも大型 LNG 船の実験船の性格を有して いる。

\section{2-3 その他の型式}

高価なメンブレンを省略しようという研究が盛んに 行なわれている。文献を整理するとだいたい次のよう な考え方に分類される。

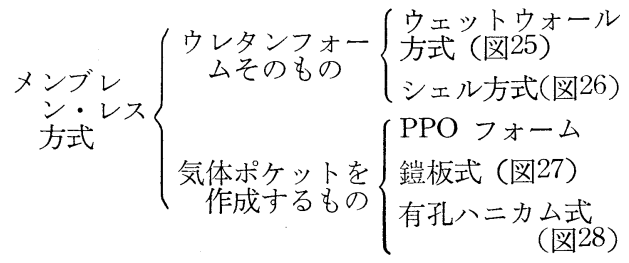

ウェットウォール方式は図のよ5に表面メッシュで 補強されたウレタンフォームに直接液が接する ${ }^{12)}$ 。シ エル方式は現在のところ LPG 程度までが対象といわ れるが, 図のごとくウレタンフォームを内面に 2 層に 分け吹き付けただけのタンクである ${ }^{13)}$ 。図15の例も考 え方はこれに近い。

一方，ガス体のポケットを作る方式では PPO フォ 一ム ${ }^{14)}$, 構造的にポケットを作成する提案 ${ }^{15)}$, 接液面

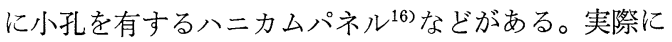
はかなりの問題が予想されるが興味ある考え方であ

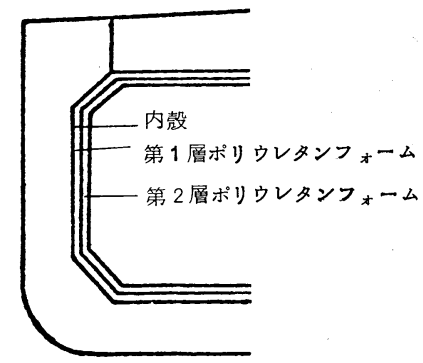

図26 ウレタンフォームを内面に吹き付けた LPG タンク

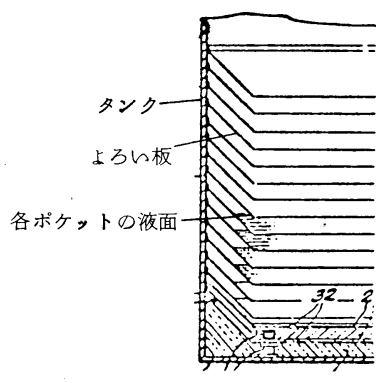

図27鎧板式タンク

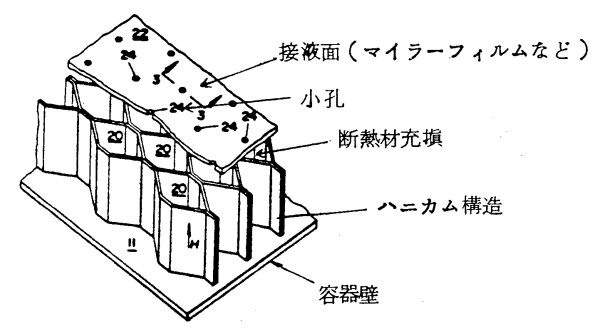

図28 有孔ハニカム型のタンク壁

る。

3. LNG 用配管の断熱

地上タンクや船舶では外殼があったり, イナートガ スが封入されたりして, 湿気侵入の心配は軽減される が，配管防熱では最も留意すべき一つが防湿構造であ ろら。防熱材は昔からフォームグラスがよく使われて きた。この材料は弾性が少ないので管との間には不凍 性シーラーが用いられる。最近の LNG 基地の配管防

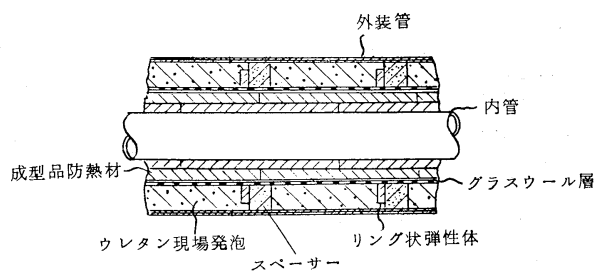

図29 東京瓦斯根岸の配管防熱

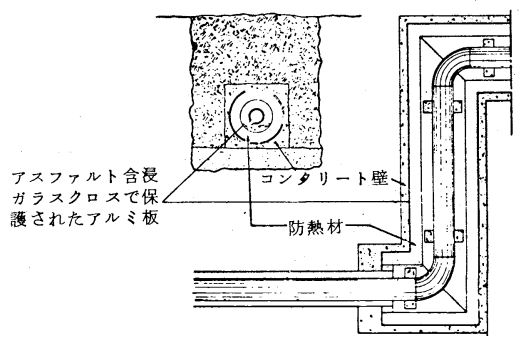

図30 ループ・エクスパンション 


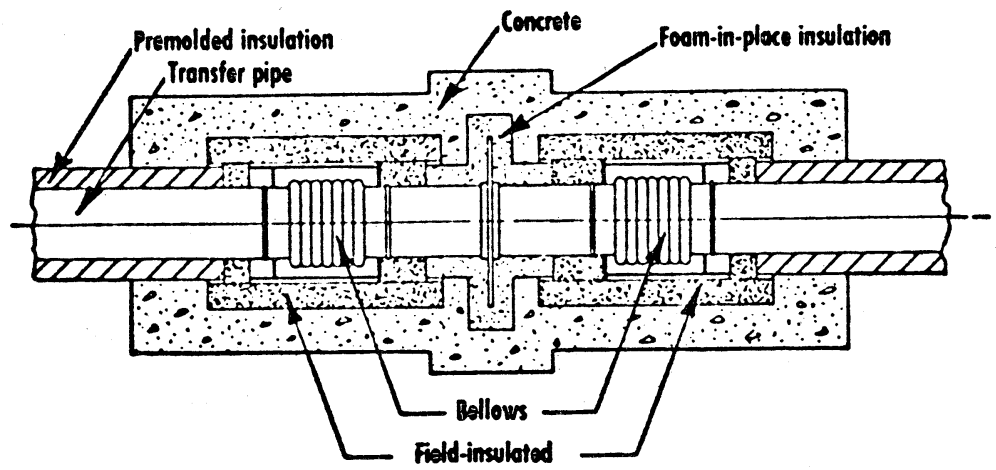

図31 ベローズ式エクスパンション

熱は明らかにポリウレタンフォームが多く使われる傾 向にある。外管は保護と防湿を兼ねた 2 重管構造がよ くみられ，管の防熱を予めプレハブ化するのに便利で ある。しかし中間にウレタンフォームを充㙗する場合 には，なんらかの方法で内外管の間を縁切りしておか なければならない。図29, これらの配虑がなされてい る17)。

長距離 LNG パイプラインは未だ実現されていない が, 研究は盛んである。この場合の大きい課題は, 一 つは防熱方法, 他の一つは伸縮対策にあるといわれ る。断熱法についてはパーライト入り真空法とポリウ レタンフォームがよく例にあげられている。伸縮対策 としてはループを作る方法 (図30), 内管にベローズ を入れる方法 (図31)，内管にインバー鋼を使用する 方法 (図32) ${ }^{18)}$, 内管をプレストレスする方法 ${ }^{19}$, あ るいはメンブレン構造の配管も提案されている20)。

完成近いブルネイ基地のタンクーバース間 3.6 マイ ルを往復する $\mathrm{LNG}$ 配管には 40 フィートの各管ごとに 工場でプレハブ式にウレタンスプレーの防熱が行なわ れた ${ }^{21}$ 。

\section{NASA における 2,3 の断熱例}

米国の宇宙ミサイルの燃料タンクの防熱法は, われ われの目標とは立場も異なるが幾つかの示唆がある。 これら研究の中心は真空多層構造で, 基本的には反射

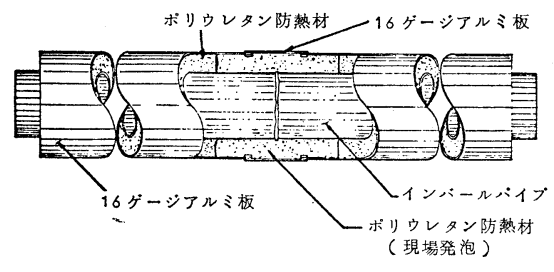

図32 インバール鋼使用の配管
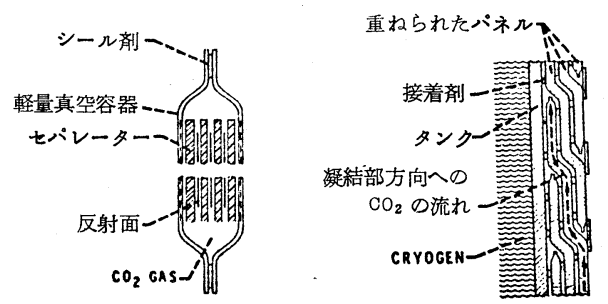

図33 自己真空式多層断熱材
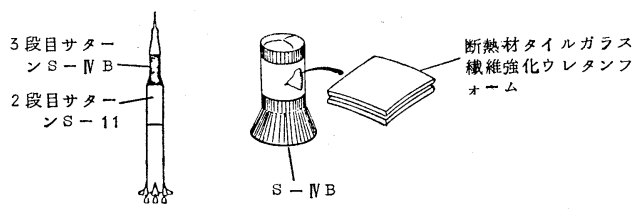

図34 サターン- V の防熱

面はマイラー蒸着フィルム, スペーサーはナイロン布 などが考えられている。真空の代りに炭酸ガスを入れ た袋入りの多層構造の研究がある。低温ではガスの凝 固のため内部は真空に近い状態が得られる。型状は図 33 左のごとく, $3^{\prime} \times 6^{\prime}$ のマット状であるが右図のごと くその装着方法が面白い22)。

アポロのサターン-V の 2 段目, 3 段目のロケット にウレタンフォームが使われた。2 段目は直径 $10 \mathrm{~m} の$ 円筒型で $\mathrm{H}_{2}$ および $\mathrm{LO}_{2}$ 用タンクがあり, この外面 に2" ないし 3" のウレタンフォームのスプレーを行 ない，次いて切削してそれぞれ 0.7 および $1^{\prime \prime}$ 厚に仕 上げ表面はナイロン布強化ポリウレタン樹脂仕上げで ある ${ }^{12)}$ 。3 段目にはタンクの内側にブロック状の防熱 板を接着し, 表面にはガラスクロス強化テフロンのラ イニングが行なわれた (図34) ${ }^{23)}$ 。

S-11 を担当したノースアメリカン, S-IV B のダ 
グラス, その他 NASA の関倸会社も LNG の断熱に 関心を有しているといわれる。今後話題が豊富になる かもしれない。

\section{文献}

1）石川島播磨重工, 実公昭45-23369

2) M. Humbert, 第 2 回国際 LNG 会議 (1970)

3）山本，超低温技術，2，(1)，48（1972）

4) A. R. Duffy et al, Oil \& Gas J., 56, (1-Aug.), 114 (1966)

5) G. H. Ewing，第 2 回国際 LNG 会議 (1970)

6) 野尻, 石油学会誌, 14，(2)，40 (1971)

7) 石川島播磨重工, 実公昭46-36910

8）住友重機械, 超低温技術, 1, (7), 93 (1971)

9) Preload，技術資料

10) W. B. Thomas, LNG/LPG Conference, London (1972)
11）造船，3 月号，24 (1972)

12）日本発条，技術資料

13）シェル, 特公昭 47-3673

14) Burkinshaw，第 1 回国際 LNG 会議 (1968) （ただし，天然ガス鉱業会，最新の LNG 情報 （昭43-11）より引用）

15）コンチ，特公昭 $35-14339$

16) マーチンマリエタ, 特開昭 $47-536$

17) 東京瓦斯, 実公昭46-21568

18) A. R. Duffy, Oil \& Gas J., 57, (8-May), 80 (1967)

19) Garder, Oil \& Gas J., 58, (1-Apr.), (1968)

20）永田, 産業機械, 30 (46年 4 月)

21) Mod. Plast. Int'l, 2, (2), 35 (1972)

22) Faddoul, J. of Cell. Plast., 4, (3), 113 (1968)

23) Mod. Plast., 47, (11), 66 (1966)

\title{
Insulation for LNG Facilities
}

\author{
H. Komada \\ (Nihon Soflan Chem. \& Eng. Co., Ltd.)
}

SYNOPSIS:-This paper summarizes the examples of many kinds of thermal insulating technology for various LNG facilities such as storage tanks, marine vessels and pipe installations mainly operating in actual use and/or expected in near future. 